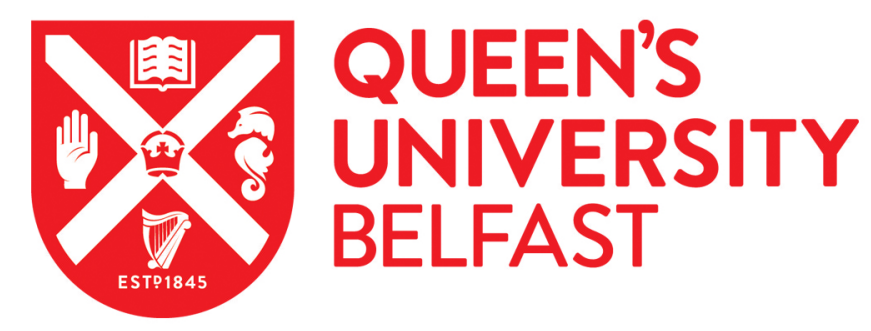

\title{
How Time Matters in the UN Human Rights Council's Universal Periodic Review: Humans, Objects, and Time Creation
}

McNeilly, K. (2021). How Time Matters in the UN Human Rights Council's Universal Periodic Review: Humans, Objects, and Time Creation. Leiden journal of International Law, 34(3), 607 - 627.

https://doi.org/10.1017/S0922156521000169

\section{Published in:}

Leiden journal of International Law

Document Version:

Publisher's PDF, also known as Version of record

Queen's University Belfast - Research Portal:

Link to publication record in Queen's University Belfast Research Portal

\section{Publisher rights}

Copyright 2021 the authors.

This is an open access article published under a Creative Commons Attribution License (https://creativecommons.org/licenses/by/4.0/), which permits unrestricted use, distribution and reproduction in any medium, provided the author and source are cited.

\section{General rights}

Copyright for the publications made accessible via the Queen's University Belfast Research Portal is retained by the author(s) and / or other copyright owners and it is a condition of accessing these publications that users recognise and abide by the legal requirements associated with these rights.

Take down policy

The Research Portal is Queen's institutional repository that provides access to Queen's research output. Every effort has been made to ensure that content in the Research Portal does not infringe any person's rights, or applicable UK laws. If you discover content in the Research Portal that you believe breaches copyright or violates any law, please contact openaccess@qub.ac.uk. 


\title{
How time matters in the UN Human Rights Council's Universal Periodic Review: Humans, objects, and time creation
}

\author{
Kathryn McNeilly* \\ School of Law, Queen's University Belfast, University Road, Belfast, County Antrim, Northern Ireland, BT7 1NN \\ Email: k.mcneilly@qub.ac.uk
}

\begin{abstract}
The Universal Periodic Review (UPR) of the United Nations Human Rights Council is an innovative monitoring mechanism in the international human rights law system. As the UPR matures, scholars have increasingly sought to stand back and understand it as a process. In this article, I take work in this vein further by considering more closely the actors involved in the UPR - humans and objects - and highlighting the time creating effects that emerge from the relationships between them. Across the various stages of the UPR, a range of temporalities - from cyclicality and linearity to retrogression and suspension of time are produced and sustained by people, reports, data, lists, microphones, screens, computers, action plans, and desks, just to name a few. I argue from this that time is materially made in the review process, often in micro and taken for granted ways. In its operation, the UPR appears as a collection of temporal assemblages. Or, in language drawn from actor-network theory (ANT), an assortment of fluid and interweaving sets of actants networked together who generate ideas of time across its practice. Apprehending time creation in this material, the ANT-inflected way is highly significant for scholars and practitioners interested in the UPR. It holds potential to influence how this process can be understood, approached, and located within international human rights law as itself a larger, time creating actor-network.
\end{abstract}

Keywords: actor-network theory; Human Rights Council; international human rights law; time; Universal Periodic Review

\section{Introduction}

As a visitor to the Swiss city of Geneva, one soon learns that time is central to its history. From the sixteenth century onwards Geneva, and Switzerland more generally, became a world-leader in watchmaking. By the end of the century, Geneva watchmakers had secured a widespread reputation for quality and established the first watchmakers' guild - Maîtrise des horlogers de Genève in 1601. This rich tradition is visibly celebrated in the city in landmarks such as l'horloge fleurie, a five-meter-wide clock face made of flowers which change with the seasons, and l'horloge du Passage Malbuisson, a clock featuring 16 bronze bells that chime each hour alongside 42 animated figures. Rather than just mapping time, however, the clocks and watches which have become closely intertwined with Geneva's history can be understood as objects intimately involved in the creation of time in relationships with humans more widely. Timekeeping devices, both

${ }^{\star}$ The research underpinning this article was facilitated by a Leverhulme Research Fellowship 2019-2020 (RF-2019-205). Sincere thanks to participants at the Global Norms in a Divided World seminar held at Queen's University Belfast in February 2020 who provided feedback on an early draft this work. Any errors remain mine alone.

(c) The Author(s), 2021. Published by Cambridge University Press. This is an Open Access article, distributed under the terms of the Creative Commons Attribution licence (http://creativecommons.org/licenses/by/4.0/), which permits unrestricted re-use, distribution, and reproduction in any medium, provided the original work is properly cited. 
personal and public, shape our understandings of social life and help to generate and sustain common conceptions of time. ${ }^{1}$ This includes, for example, the development of standardized time in the late nineteenth century. ${ }^{2}$ Mechanical timekeeping devices have, for centuries, worked alongside humans in the production of temporal rhythms which guide our daily lives from the micro to the macro. Together they do not map a pre-existing time but produce the time we assume to be natural and pre-existing. Yet, for the international human rights lawyer, this is not the only set of human-nonhuman relationships with time creating significance linked to Geneva.

If the visitor travels just over three kilometres from the clocks noted above, another of the city's landmarks can be found: the Palais des Nations. This is of course the European headquarters of the United Nations (UN), and a key site for international human rights law. Within this building, and in a range of wider activities connected to it, time is also created and done so in material ways via everyday relationships between humans and objects. In this article I explore this assertion in the context of a central international human rights law mechanism whose practice is closely tied to Geneva: The UPR. In this process, various temporalities - from cyclicality and linearity to retrogression and suspension of time - are produced and sustained by people, reports, data, lists, microphones, screens, computers, action plans, and desks, just to name a few. I argue from this that the UPR can be understood as a collection of temporal assemblages. ${ }^{3}$ Or, in language drawn from ANT, ${ }^{4}$ an assortment of fluid and interweaving sets of actants networked together who operate to generate ideas of time across the various stages of the review's practice. Apprehending time creation in the UPR in this material way changes how it is possible to understand this process, approach it, and locate it within the wider international human rights law system. This way of understanding the UPR anew builds on existing literature which has noted the role of objects in the Review. ${ }^{5}$ It extends this line of thinking further by encouraging consideration of the temporal effects that these objects generate in networks with humans. This allows scholars and practitioners to think deeply about the UPR as a time generating activity, grasping the mundanity and often taken for granted nature of time creation in its process. ${ }^{6}$

My argument proceeds in three parts. In Section 2 I provide contextual information on the UPR as an international human rights law monitoring mechanism, on ANT, and on law and time thinking. In doing so, the discussion in this section maps the novelty of understanding the UPR via a focus on material time creation. Following this, in Section 3 I analyse the four formal stages of the UPR process and highlight the various locations where human-nonhuman networks generate ideas of time within themselves. This is informed by documentary analysis of UPR reports and materials, ${ }^{7}$ review of online UPR webcast archives, and the observation of the $35^{\text {th }}$ session of the

\footnotetext{
${ }^{1} \mathrm{~K}$. Birth, Objects of Time: How Things Shape Temporality (2012), 35-70.

${ }^{2}$ C. J. Greenhouse, A Moment's Notice: Time Politics Across Cultures (1996); Y. Yanovsky, 'Clocks', in M. B. Salter (ed.), Making Things International 1: Circuits and Motion (2015), 348; G. Gordon, 'Railway Clocks', in J. Hohmann and D. Joyce (eds.), International Law's Objects (2018), 387.

${ }^{3}$ The term 'assemblage' stems from G. Deleuze and F. Guattari, A Thousand Plateaus: Capitalism and Schizophrenia (1987).

${ }^{4}$ Explored further below. For an overview see B. Latour, Reassembling the Social: An Introduction to Actor Network Theory (2005). On the relationship between ANT and assemblage thinking see M. Müller, 'Assemblages and Actor-networks: Rethinking Socio-material Power, Politics and Space', (2015) 9 Geography Compass 27.

${ }^{5}$ J. K. Cowan, 'The UPR as a Public Audit Ritual: An Anthropological Perspective on Emerging Practices in the Global Governance of Human Rights', in H. Charlesworth and E. Larking (eds.), Human Rights and the Universal Periodic Review: Rituals and Ritualism (2014), 42; J. Billaud, 'Keepers of the Truth: Producing "Transparent" Documents for the UPR', in Charlesworth and Larking, ibid., at 63.

${ }^{6}$ On the mundanity of legal time and its material generation see E. Grabham, Brewing Legal Times: Things, Form, and the Enactment of Law (2016), 11.

${ }^{7} \mathrm{UN}$ documentation related to the first and second review of 31 states was examined, with diversity secured across geographical location and state size. The included states were: Afghanistan, China, the Democratic People's Republic of Korea, India, Israel, Algeria, the Democratic Republic of the Congo, The Gambia, South Africa, Nigeria, Canada, Cuba, the United States of America, Mexico, Guatemala, Brazil, Peru, Chile, Colombia, Venezuela, Albania, Austria, Germany, the United Kingdom, Sweden, Russia, Australia, Papua New Guinea, Nauru, New Zealand, and Indonesia. The first and second cycles were selected as the focus for research as the third cycle was still ongoing at the time of the research project (September 2019August 2020).
} 
UPR in Geneva. ${ }^{8}$ Across all four stages, objects appear to work alongside humans in relationships to create diverse temporal ideas and rhythms. The temporalities detected in this analysis are constructed in micro and everyday ways, and their networked creation is often invisible. In Section 4, I outline the significance of this analysis for scholars and practitioners interested in the UPR. This includes the question how this mechanism can be understood anew - as relational and productive - and, potentially, approached differently through more thoughtful engagement with objects and addressing the limitations of dominant temporal flows created by actants. It also includes how the UPR may be apprehended as one node linking into wider actor-networks generating time in the international human rights law system more broadly. In this respect, the UPR offers a useful starting point for efforts to better apprehend the material time creation at work across this area of law.

\section{Situating the Universal Periodic Review, actants, and time}

Created as part of the new Human Rights Council in 2006, the UPR is an innovative monitoring development. Designed to address the shortcomings of the Council's predecessor, the Commission on Human Rights, the UPR is grounded in the values of universality, equality and transparency. It constructed a system whereby the human rights obligations of all UN member states are peer reviewed in a periodic manner, complementing treaty body monitoring structures. ${ }^{9}$ The initial periodicity of the review was specified as four years. ${ }^{10}$ In the second cycle, however, this was extended to four and a half years, with a break inserted between cycles two and three leading to a most recent periodicity of five years. ${ }^{11}$ In the review, states are examined on their obligations under the UN Charter, the Universal Declaration of Human Rights, the international human rights instruments to which they are party, any voluntary commitments or pledges made, and 'applicable international humanitarian law'. ${ }^{12}$ Since 2008, all 193 member states have been subject to review, many for the third time as the mechanism moves towards completion of its third cycle in 2022.

The process has four formal stages. ${ }^{13}$ Firstly, information is collated on the state's human rights record in the period to be reviewed. This involves the creation of a national report submitted by the state under review (SuR), and two reports summarizing information from UN bodies and civil society stakeholders. The latter two documents are compiled by the Office of the High Commissioner for Human Rights (OHCHR). Secondly, a meeting of the UPR Working Group occurs in Geneva, transmitted globally via webcast. In this meeting Human Rights Council member and observer states scrutinize the SuR's record, offering comments, questions, and recommendations for action in an 'interactive dialogue' with the SuR. An outcome report from the UPR Working Group is drafted by a troika of three Human Rights Council member states with support from the Secretariat. This report summarizes the meeting and records all recommendations made, which the SuR must either support or 'note'. ${ }^{14}$ The report is adopted by the Working Group at a

\footnotetext{
${ }^{8}$ 20-31 January 2020. I observed sessions during this period from the public gallery in Salles XX. Ethical approval for this research was granted by the School of Law, Queen's University Belfast.

${ }^{9}$ F. D. Gaer, 'A Voice Not an Echo: Universal Periodic Review and the UN Treaty Body System', (2007) 7 Human Rights Law Review 109, at 109-12.

${ }^{10}$ UN HRC, Institution-building of the United Nations Human Rights Council, UN Doc. A/HRC/RES/5/1 (2007), at para. 14 .

${ }^{11}$ S. Bertotti, 'Separate or Inseparable? How Discourse Interpreting Law and Politics as Separable Categories Shaped the Formation of the UN Human Rights Council's Universal Periodic Review', (2019) 23 International Journal of Human Rights 1140 , at 1145 .

${ }^{12}$ See UN Doc. A/HRC/RES/5/1 (2007), supra note 10, Ann., paras. 1-2.

${ }^{13}$ A. Mulugeta Abebe, 'Of Shaming and Bargaining: African States and the Universal Periodic Review of the United Nations Human Rights Council', (2009) 9 Human Rights Law Review 1, at 7.

${ }^{14}$ See UN Doc. A/HRC/RES/5/1 (2007), supra note 10, para. 32.
} 
separate session within 48-72 hours. Thirdly, at the next Plenary session of the Human Rights Council three to four months later, the outcome of the review is formally adopted. At this session there is further opportunity for states to comment, as well as for National Human Rights Institutions (NHRIs) and non-governmental organizations (NGOs) to make statements. Fourthly, and finally, a follow-up stage begins where the SuR must act on recommendations accepted in the intervening period before the next review. ${ }^{15}$

In the first decade of its existence, much scholarly attention has been dedicated to examining the UPR experience of particular states ${ }^{16}$ as well as to assessing whether the UPR has, or has not, enhanced fulfilment of human rights obligations. ${ }^{17}$ In recent years, as the mechanism matures, scholars have sought to stand back and understand the UPR more generally as a phenomenon warranting examination in and of itself. In the latter category of writing, the ideas of ritual and ritualism, ${ }^{18}$ public audit, ${ }^{19}$ and the distinction between law and politics ${ }^{20}$ are just three devices which have been employed to analyse the mechanism's operation and routine activity. Through this work, academics and practitioners have begun to think through and comprehend the nature of the UPR on a more structural level. I aim to add to this still-developing body of work which focuses on deeper understanding of the UPR as a process. To do so, I propose engaging in a closer investigation of the actors involved in the review and the effects that they generate. These include humans but also, importantly, objects, who can be apprehended to operate together in various relational assemblages, or networks.

In making this statement, I am engaging the tools of ANT. Emerging in science and technology studies from the 1980 s onwards via thinkers such as Bruno Latour, ${ }^{21}$ Michel Callon, ${ }^{22}$ John Law, ${ }^{23}$ Annemarie Mol, ${ }^{24}$ and Marilyn Strathern, ${ }^{25}$ ANT sets out to explore 'science in the making' in contrast to 'ready made science and technology'. ${ }^{26}$ Through this ANT provides a fuller account of the socio-technical world and its nuances. ANT cannot be reduced to one overarching theory or approach and is often best discerned as something that is undertaken as opposed to summarized. Grounded in empirical case studies of science and technology processes - exploration of scallop farming, ${ }^{27}$ the failed development of a rapid transport system, ${ }^{28}$ diagnosis and treatment of

\footnotetext{
${ }^{15}$ Ibid., paras. $33-8$.

${ }^{16}$ L. Cochrane and K. McNeilly, 'The United Kingdom, the United Nations Human Rights Council and the First Cycle of the Universal Periodic Review', (2013) 17 International Journal of Human Rights 152; R. Smith, “'To see Themselves as Others see Them": The Five Permanent Members of the Security Council and the Human Rights Council's Universal Periodic Review', (2013) 35 Human Rights Quarterly 1; E. Jordaan, 'Elephants in the Room: Botswana and the United Nations Universal Periodic Review', (2019) 37 Nordic Journal of Human Rights 42; J. T. Chow, 'North Korea's Participation in the Universal Periodic Review of Human Rights', (2017) 71 Australian Journal of International Affairs 146.

${ }^{17}$ E. Domínguez Redondo, 'The Universal Periodic Review of the United Nations Human Rights Council: An Assessment of the First Session', (2008) 7 Chinese Journal of International Law 721; N. Higgins, 'Creating a Space for Indigenous Rights: The Universal Periodic Review as a Mechanism for Promoting the Rights of Indigenous People', (2019) 23 The International Journal of Human Rights 125; F. Cowell and A. Milon, 'Decriminalisation of Sexual Orientation Through the Universal Periodic Review', (2012) 12 Human Rights Law Review 341; G. Patel, 'How "Universal” is the United Nations Universal Periodic Review Process? An Examination of the Discussions Held on Polygamy', (2017) 18 Human Rights Review 459.

${ }^{18}$ See Charlesworth and Larking, supra note 5.

${ }^{19}$ See Cowan, supra note 5.

${ }^{20}$ See Bertotti, supra note 11.

${ }^{21}$ B. Latour and S. Woolgar, Laboratory Life: The Construction of Scientific Facts (1986); B. Latour, The Pasteurization of France (1988)

${ }^{22}$ M. Callon, 'Some Elements of a Sociology of Translation: Domestication of the Scallops and the Fishermen of St Brieuc Bay’, (1984) 32 The Sociological Review Monograph 196.

${ }^{23}$ J. Law, Organizing Modernity: Social Ordering and Social Theory (1993).

${ }^{24}$ A. Mol, The Body Multiple: Ontology in Medical Practice (2003).

${ }^{25}$ M. Strathern, 'Cutting the Network', (1996) 2 The Journal of the Royal Anthropological Institute 517.

${ }^{26}$ B. Latour, Science in Action: How to Follow Scientists and Engineers Through Society (1988), 13.

${ }^{27}$ Callon, supra note 22.

${ }^{28}$ B. Latour, Aramis, or the Love of Technology (1993).
} 
disease $^{29}$ are just some examples - ANT is characterized by the researcher following actors as they exist in complex, but often everyday, networks. This allows ANT scholars to open the 'black box' of the phenomenon under study and unpack the relational materiality which it involves. Importantly, in this task ANT adopts a flat ontology. Both human and nonhuman actors - or, for Latour, actants ${ }^{30}$ - are understood to operate within networks whereby their identity is defined by their interaction with, and modification of, each other. Humans, machines, animals, texts, hybrids all have a role to play. As Callon and Law elaborate:

often in practice we bracket off non-human materials, assuming they have a status which differs from that of a human. So materials become resources or constraints; they are said to be passive; to be active only when they are mobilised by flesh and blood actors. But if the social is really materially heterogeneous then this asymmetry doesn't work very well. ${ }^{31}$

Accordingly, ANT does not limit in advance the sort of beings that populate the social world ${ }^{32}$ and regards both human and nonhuman actants as essential to sociotechnical processes. Rather than asserting that objects have a complete agency and can determine action, ANT scholars see many metaphysical states between full causality and sheer inexistence for objects in relationships with humans. ${ }^{33}$ From this ANT proposes what Mol terms an 'ontological politics', which views the world as multiple and performative. ${ }^{34}$ Since the 1980 s ANT has stimulated many new avenues of thought, including post-ANT scholarship, ${ }^{35}$ object-orientated ontology, ${ }^{36}$ thing theory, ${ }^{37}$ and wider post-human approaches. ${ }^{38}$

ANT has now been engaged in areas beyond science and technology studies. This includes the deployment of ANT tools in law in various locations and contexts, ${ }^{39}$ forming one strand of the wider attention to legal materiality which has grown in recent years. ${ }^{40}$ One particular study to note is Latour's own investigation of the Counseil d'État which assists in understanding law as a network of people and things including concepts, documents, architecture, and everyday office objects. ${ }^{41}$ Drawing our attention to international human rights law and, specifically, to the UPR, ANT tools have indeed already been introduced to begin to better understand the operation of this monitoring mechanism and the material relationality it involves. Referring to the UPR as an 'untidy and unruly "assemblage" of people, objects, texts and utterances', ${ }^{2}$ Jane Cowan has aimed to highlight:

\footnotetext{
${ }^{29}$ See Mol, supra note 24 .

${ }^{30} \mathrm{~B}$. Latour, The Politics of Nature: How to Bring the Sciences into Democracy (translated by C. Porter) (2004), 75.

${ }^{31} \mathrm{M}$. Callon and J. Law, 'After the Individual in Society: Lessons on Collectivity from Science, Technology and Society', (1997) 22 Canadian Journal of Sociology 165, at 168.

${ }^{32}$ See Latour, supra note 4 , at 12.

${ }^{33}$ Ibid., at 72 .

${ }^{34}$ A. Mol, 'Ontological Politics. A Word and Some Questions', (1999) 47 The Sociological Review 74.

${ }^{35}$ J. Law and J. Hassard (eds.), Actor Network Theory and After (1999).

${ }^{36}$ G. Harman, 'An Outline of Object-Orientated Philosophy', (2013) 96 Science Progress 187.

${ }^{37}$ B. Brown (ed.), Things (2004).

${ }^{38}$ D. J. Haraway, Simians, Cyborgs, and Women: The Reinvention of Nature (1991); N. K. Hayles, How We Became Posthuman (1999); R. Braidotti, The Posthuman (2013).

${ }^{39} \mathrm{M}$. Strathern, 'What is Intellectual Property After?', in Law and Hassard, supra note 35, at 156; T. Scheffer, Adversarial Case-Making: An Ethnography of English Crown Court Procedure (2010); A. Pottage, 'The Materiality of What?', (2012) 39 Journal of Law and Society 167; E. Cloatre, Pills for the Poorest: An Exploration of TRPS and Access to Medication in SubSaharan Africa (2013).

${ }^{40}$ H. Y. Kang, 'Law's Materiality: Between Concrete Matters and Abstract Forms, or How Matter Becomes Material', in A. Philippopoulos-Mihalopoulos (ed.), Routledge Handbook of Law and Theory (2018), 453; H. Y. Kang and S. Kendall, 'Legal Materiality', in S. Stern, M. Del Mar and B. Meyler (eds.), The Oxford Handbook of Law and Humanities (2020), 21.

${ }^{41}$ B. Latour, The Making of Law: An Ethnographic Study of the Counseil d'État (2010).

${ }^{42}$ Cowan, supra note 5 , at 45 .
} 
not only how different human actors are trying to intervene in the UPR and what they want to achieve, but also ... how clocks, queues, bicycles, badges, cell phones, internet portals, simultaneous translation, NGO fact sheets, speakers' lists and the upr-info.org database, among other things "act" to invite, shape, channel or block those human efforts. ${ }^{43}$

Julie Billaud has similiarly aimed to open up the 'black box' of the OHCHR UPR document compilation process, basing her research on an internship doing this very work. ${ }^{44}$ This existing thinking is a starting point that stands to be expanded. While Cowan does refer to human and nonhuman actants, her overarching focus is on exploration of the UPR as a public audit ritual. Billaud's research is closer to a dedicated ANT investigation, albeit it is limited to the stage of document compilation alone. Much remains to be done, therefore, to take this material-focused sensibility further and more deeply understand the work that actor-networks perform throughout all stages of the UPR process.

One element of this performed work which has been overlooked to date is how such networks operate to produce ideas of time in the UPR. Humans and objects can be observed working together to generate temporalities that include linearity, cyclicality, revision, retrogression, disruption, transition, past, present, future, and suspension of time across the various stages of the review. In making this statement, an ANT-inflected perspective is brought into conversation with thinking on law and time. This latter literature advances that time is not a natural backdrop against which legal processes take place, rather, law produces time in its daily operation. ${ }^{45}$ In the words of Emily Grabham, legal institutions, structures and activities operate to 'brew time'. ${ }^{46}$ Grabham's insights are particularly useful for the current study as, drawing on object-orientated perspectives including ANT, she observes this brewing to involve humans and objects in relationships as 'cells, tests, forms, reports, legal technicalities and documents contribute, alongside people, to the materialisation of time in legal networks'. ${ }^{47}$ Grabham explores this assertion in relation to national law, where indeed most law and time scholarship has been focused. The closest scholars have come to investigating this kind of legal time creation at the international legal level is Annelise Riles's work on the 1995 Beijing Women's Conference. While not explicitly focused on time, Riles reveals how brackets placed around the word 'gender' in the Platform for Action text during negotiations created temporal ideas such as an interminable present and retrogression. ${ }^{48}$ Here brackets emerge as important temporal actants that must be attended to alongside human delegates. Scope exists to more consciously extend thinking on the material generation of time in the international legal system. Bringing this impetus to the UPR, it is possible to gain an insight into the mattering of time - its construction in material ways - in this process which has not yet emerged in work to date.

I seek to look anew at the UPR via the lens of a combined ANT and law and time perspective, highlighting how and where diverse networks of actants produce time within its process. To undertake this investigation, the discussion to follow is broken down into the four stages of the process noted earlier: collation of information on the human rights record of the SuR; the UPR Working Group sessions; adoption of the final report at the Human Rights Council Plenary; and follow-up to the review. Of course, there is more to the UPR than these activities alone. For example, consultation work and planning at state-level, lobbying and engagement between NGOs and diplomats, discussions in corridors, cafés and the Palais des Nations

\footnotetext{
${ }^{43}$ Ibid.

${ }^{44}$ See Billaud, supra note 5.

${ }^{45}$ C. J. Greenhouse, 'Just in Time: Temporality and the Cultural Legitimation of Law', (1989) 98 Yale Law Journal 1631; R. Mawani, 'Law as Temporality: Colonial Politics and Indian Settlers', (2014) 4 UC Irvine Law Review 65; M. L. Dudziak, 'Law, War and the History of Time', (2010) 98 California Law Review 1669.

${ }^{46}$ Grabham, supra note 6.

${ }^{47}$ Ibid., at 6.

${ }^{48}$ A. Riles, The Network Inside Out (2000); A. Riles (ed.), Documents: Artifacts of Modern Knowledge (2006).
} 
Serpent Bar, the UPR pre-sessions, and parallel events, etc. are also important elements. ${ }^{49}$ The four formal, public-facing stages of the process noted above, however, offer a starting point to begin to think more deeply about humans, objects and time creation. Across these stages a range of actants interact in fluid and dynamic ways to generate diverse temporalities at different points in the process. Rather than taking a grand form, these temporalities are often micro in nature, generated in routine interactions, ${ }^{50}$ and are frequently naturalized to the point that they might be missed or taken for granted.

\section{Material time creation in the Universal Periodic Review}

\subsection{Stage one: Collation of information on the human rights record of the SuR}

To begin the review process, the three central report documents noted above must be created. The $\mathrm{SuR}$ is required to submit a national report on human rights protection within the relevant period which should comply in terms of form and content with guidelines provided by the Human Rights Council. ${ }^{51}$ The deadline for submission of the report in Microsoft Word format is formally communicated in writing to the SuR by the OHCHR once the date of the review is set. As a guide, this is usually twelve to thirteen weeks in advance. The SuR is instructed to submit its report via email to the UPR Branch of the OHCHR. ${ }^{52}$ Stakeholders, with and without consultative status with the UN Economic and Social Council, are also invited to submit information which must similarly follow guidelines in terms of content, presentation and word limit. ${ }^{53}$ These files must be submitted around six months before the review date, adhering to a deadline which is posted on the OHCHR website. Stakeholder submissions should also be submitted in Word format and are uploaded to an online submission system. They are then recorded in a registry, ${ }^{54}$ and enter the compilation process whereby information is summarized to produce the final collective stakeholder summary report. UN entities can submit written information by the same deadline as stakeholders. This is fed into the UN summary report alongside documentation such as treaty monitoring body concluding observations and Special Procedures reports already available to the OHCHR.

In this process, an important temporality is created: cyclicality. Submission of documentation by the deadlines set is essential to ensure SuR and stakeholder activity around the review is in harmony with the UPR schedule, to make certain that material is ready for reviews, and to maintain the cyclical rhythm of the process overall. It also ensures that the regular periodic scrutiny of all states - the overarching raison d'être for the system - is not compromised. The submission process, therefore, is one part of a wider generation of cyclicality which drives the UPR as a periodic mechanism. For submission activities human actors - including state representatives, NGO and UN workers who create and submit files, Secretariat staff who set deadlines and receive the files - play an important rule, but other actors are essential too. Dates, their circulation in written communication or in a table hosted online, computers, Microsoft Word software, internet connection, email accounts, the online submission system, electronic files, and the registry of

\footnotetext{
${ }^{49}$ For discussion of some of these wider elements see F. McGaughey, 'The Role and Influence of Non-governmental Organisations in the Universal Periodic Review - International Context and Australian Case Study', (2017) 17 Human Rights Law Review 421.

${ }^{50}$ As noted previously, this echoes Grabham's findings at the level of national law, supra note 6.

${ }^{51}$ UN HRC, Follow-up to the Human Rights Council Resolution 16/21 with Regard to the Universal Periodic Review, UN Doc. A/HRC/DEC/17/119 (2011), at para. 2. See also updates at www.upr-info.org/sites/default/files/general-document/pdf/ ohchr_guidance_national_report_3rdcycle_en.pdf (accessed 31 January 2021).

${ }^{52}$ The submission process here, and the compilation and reading processes discussed below, largely take place in electronic form. This differs from the physical nature of files and their exploration in many original ANT analyses, including Latour's study of files in the Counseil d'État, supra note 41.

${ }^{53}$ See www.ohchr.org/en/hrbodies/upr/pages/ngosnhris.aspx (accessed 31 January 2021).

${ }^{54}$ See Billaud, supra note 5 , at 76.
} 
stakeholder submissions also contribute to the production of a cyclical temporal rhythm in this stage. These actants work together, and without objects the successful creation of cyclicality in the submission process would not be possible. For example, the NGO worker creates the file on a computer, the internet connection facilitates navigation to the UPR webpage via a keyboard and mouse, the online submission system transmits the file to the Secretariat staff who consequently log it in a registry. All of these actants are necessary for submission to occur and to ensure the cycle's calendar is maintained.

Once files have been received, formatting (the national report) and compilation (the stakeholder and UN summary reports) begins. Here another temporality is created: predictability. The UPR reader knows what each document will look like, how long it will be, and the general manner in which its contents will be presented. This predictability is generated by Secretariat staff who undertake the formatting and compilation work, but they do not do so alone. Guideline documents containing instructions on format and page limits, OHCHR policy documents detailing what can and cannot be included in compilation, the UN logo and document templates, computers and software programmes are all partners in this activity. ${ }^{55}$ Together these actants ensure that each document includes the UN logo in the top left-hand corner, has a UN document number, begins with the date of its creation, specifies the language of the original file, details the session within which the review will take place, etc. In UN and stakeholder summaries, additional predictability emerges. Five standard sections are used, the document begins with a text box containing a disclaimer regarding content, information on the periodicity of the review, the number of stakeholders who submitted information, etc., and information is summarized throughout in a detached way using similar linguistic patterns.$^{56}$ More than just creating an aesthetic ${ }^{57}$ alone, this network of human staff, policy documents, templates, formatting and so on ensures that the reader knows what these documents will look like before they are released, generating predictability around information presented which extends across all reviews. Unfortunately, this may lead to a lack of urgency in the highlighting of human rights violations, ${ }^{58}$ especially in the stakeholder and UN summaries where urgent concerns may be most likely to be raised. The compilation of a wide range of information, predetermined headings and formatting, and the sheer volume of obligations to be covered within a strict page limit, are not highly compatible with the creation of temporal rhythms of urgency.

Following formatting/compilation, UPR documents are made available to reviewing states (via the UN extranet) and to the public more widely (via the OHCHR website). Once released, they generate additional ideas of time which are transmitted in their reading via the work of objects either internal to the document itself or external but invoked within in. The first of these temporalities is a sense of the past. Across all reports, a range of issues, concerns and achievements regarding human rights in the period under review are recalled. The reader is invited to step into this past. In UN and stakeholder summaries, an important way this is achieved is via the insertion of footnotes signposting towards the original stakeholder document advancing the recollection in question. In their insertion footnotes bring together a range of voices, perspectives and past experiences pertaining to the period under review which the reader encounters in the present. In the UN summary report a number of standard tables are also important in bringing the past into the present. For example, the 'Reporting Status'/'Cooperation with Treaty Bodies' table featured in the second section details the SuR's engagement with treaty bodies, noting the last concluding observations, reports submitted, and where reports are overdue. Through this table a picture of past

\footnotetext{
${ }^{55}$ For wider discussion of the predictable, standardization of legal documents see E. Cloatre and D. Cowan, 'Legalities and Materialities', in A. Philippopoulos-Mihalopoulos (ed.), Routledge Handbook of Law and Theory (2019) 433, at 436-7.

${ }^{56}$ See Billaud, supra note 5 , at 75.

${ }^{57}$ Ibid., at 64 .

${ }^{58} \mathrm{H}$. Charlesworth and E. Larking, 'Introduction: The Regulatory Power of the Universal Periodic Review', in Charlesworth and Larking, supra note 5, at 16.
} 
compliance with UN mechanisms is created, evidencing the seriousness with which the SuR has taken its monitoring obligations.

When it comes to the national report, an interesting element of the past often created relates to the history of the SuR. While the UPR aspires to take place in a largely decontextualized manner to ensure universality, ${ }^{59}$ contextualization of the human rights record in the particular SuR does frequently emerge from the national report. This may include information on how the state was established, on its role as a longstanding leader of human rights or as recently committed, and on experiences of revolutions, wars, or other civil unrest. This past as a backdrop to the present review is generated by Constitutional documents, dates, data on conflict, lists of treaties signed or ratified, and lists of instances of co-operation with UN bodies which appear in the document. Sometimes the past created via these external objects is one of linear and steady progress. Alternatively, it can be one of transition where an era of undemocratic rule has ended and a new human rights compliant regime has emerged. For example, in its first cycle report The Gambia made reference to key dates, documents, and data which together acted to produce the state's past and its significance in shaping current human rights challenges: 1965 (independence from Britain); 1994 (the date of military coup); 1996 (return to civil rule); the new Constitution of 1997 ; and the $\$ 390$ per capita income (one of the lowest in the world). ${ }^{60}$ These objects act as anchoring points in the creation of a past which is particular to the state in question. Such objects float through the pages of national reports, generating a sense of the SuR's longer-term past as of relevance to scrutiny of its record in the present.

This conjuring of the past in the present promotes a temporal linearity whereby the past and present progressively follow one another. This is furthered in the way in which report documents also generate ideas of linear progress, or lack of it. Readers - especially, very importantly, reviewing states - are invited to apprehend that the SuR has either made progress in advancing human rights, or that improvements have been at a standstill. This cannot be achieved convincingly by the human author(s)/compiler(s) alone. Various objects assist in stimulating one or more of these temporalities. One of the most frequently engaged is data. Statistical information on mortality rates, poverty, employment, representation of women in public life, asylum applications, homicide rates, violence against women, and a range of other human rights issues are frequently used to stimulate a sense of progress, or lack of it. For example, progress was generated by a German national report with reference to asylum data in the state, ${ }^{61}$ and India with reference to data on female literacy. ${ }^{62}$ A UN summary report for South Africa stimulated a sense of lack of progress through data on land restitution claims, ${ }^{63}$ and the stakeholder summary report for Nigeria did the same with reference to data on child marriage. ${ }^{64}$ Alongside data, legislation, bills, action plans, policies, and targets (including the Sustainable Development Goals) help create the same effect. Sometimes formatting devices such as lists, bullet points, ${ }^{65}$ and bold/italic/underlined text also stress a particular object and serve to generate an associated temporal rhythm. For

\footnotetext{
${ }^{59}$ J. K. Cowan and J. Billaud, 'The "Public" Character of the UPR: Contested Concept and Methodological Challenge', in R. Niezen and M. Sapignoli (eds.), Palaces of Hope: The Anthropology of Global Organizations (2017) 106, at 116.

${ }^{60} \mathrm{UN}$ HRC, National Report in accordance with para. 5 of the annex to Human Rights Council Resolution 16/21: Gambia, UN Doc. A/HRC/WG.6/7/GMB/1 (2010).

${ }^{61} \mathrm{UN}$ HRC, National Report in accordance with para. 5 of the annex to Human Rights Council Resolution 16/21: Germany, UN Doc. A/HRC/WG.6/4/DEU/1 (2008), para. 22.

${ }^{62}$ UN HRC, National Report in accordance with para.5 of the annex to Human Rights Council Resolution 16/21: India, UN Doc. A/HRC/WG.6/1/IND/1 (2008), para. 56.

${ }^{63} \mathrm{UN}$ HRC, Compilation Prepared by the Office of the High Commissioner for Human Rights in accordance with para.5 of the annex to Human Rights Council Resolution 16/21: South Africa, UN Doc. A/HRC/WG.6/1/ZAF/2 (2008), para. 15.

${ }^{64} \mathrm{UN}$ HRC, Summary Prepared by the Office of the High Commissioner for Human Rights in accordance with para.5 of the annex to Human Rights Council Resolution 16/21: Nigeria, UN Doc. A/HRC/WG.6/17/NGA/3 (2013), para. 49.

${ }^{65}$ For discussion of bullet points in ANT-inflected work see M. Strathern, 'Bullet-Proofing: A Tale from the United Kingdom', in Riles (2006), supra note 48, at 181-205.
} 
example, a list of legislation enacted since the previous review has the effect of creating progress, ${ }^{66}$ as do new initiatives or achievements listed in bold. ${ }^{67}$

Beyond these generic objects relevant to many human rights issues, often the nonhuman actants observable are unique to the discussion at hand. These include - to name just a few asylum application forms, weapons/tasers, birth certificates, electricity, drinking waters, visas, contracts, vaccinations, land, and oil. Again, these objects either guide the reader into a temporal rhythm of progress towards ultimate human rights achievement in the SuR, or one where progress has stalled. For example, asylum applications prioritized and completed can be brought into view, ${ }^{68}$ or those stuck in a backlog. ${ }^{69}$ On occasions the objects in question are more unusual. Prosthetic limbs in the second national report of the Democratic People's Republic of Korea created a narrative of progress regarding health provision. The state engaged the fact that these objects had been provided to those who needed them to create a sense of forward-moving momentum in relation to health. ${ }^{70}$ A Native American schoolboy's hair in the United States of America's first national report, evidenced progress made in religious freedom which allowed students to wear their hair in accordance with their religious beliefs. ${ }^{71}$ Kitchen facilities and utensils in the UK's first cycle stakeholder summary report generated a lack of progress on support for asylum seekers, as individuals were required to share these facilities and utensils in tension with their cultural or religious background. ${ }^{72}$ Reindeer in both the second national report and stakeholder summary report for Sweden stimulated progress and lack of it respectively regarding land rights for the indigenous Sámi people. ${ }^{73}$ These examples demonstrate how temporalities of progress, or lack of it, are created not only by words, formatting techniques and other objects internal to the document, but by invoking objects which are external and specific to the human rights issue at hand. These eclectic objects float throughout UPR documentation and work to help bring into being temporal movements and flows in a convincing way. Without them, progress or lack of it would be much harder to conjure for the reader.

While the progress/lack of progress binary and its associated linear temporality is dominant, on occasions linearity can be broken with the generation of retrogression. ${ }^{74}$ This occurs most frequently, as might be predicted, in UN and stakeholder summaries where objects play a key role in leading the

\footnotetext{
${ }^{66}$ For example, UN HRC, National Report in accordance with para.5 of the annex to Human Rights Council Resolution 16/21: Bolivarian Republic of Venezuela, UN Doc. A/HRC/WG.6/26/VEN/1 (2016), para. 30; UN HRC, National Report in accordance with para.5 of the annex to Human Rights Council Resolution 16/21: Nauru, UN Doc. A/HRC/WG.6/23/NRU/1 (2015), para. 1.

${ }^{67}$ For example, UN HRC, National Report in accordance with para. 5 of the annex to Human Rights Council Resolution 16/21: Germany, UN Doc. A/HRC/WG.6/16/DEU/1 (2013).

${ }^{68} \mathrm{UN}$ HRC, National Report in accordance with para.5 of the annex to Human Rights Council Resolution 16/21: United States of America, UN Doc. A/HRC/WG.6/22/USA/1 (2015), para. 67.

${ }^{69} \mathrm{UN}$ HRC, Summary Prepared by the Office of the High Commissioner for Human Rights in accordance with para. 5 of the annex to Human Rights Council Resolution 16/21: South Africa, UN Doc. A/HRC/WG.6/1/ZAF/3 (2008), para. 34.

${ }^{70} \mathrm{UN}$ HRC, National Report in accordance with para.5 of the annex to Human Rights Council Resolution 16/21: Democratic People's Republic of Korea, UN Doc. A/HRC/WG.6/19/PRK/1 (2014), para. 108.

${ }^{71}$ UN HRC, National Report in accordance with para.5 of the annex to Human Rights Council Resolution 16/21: United States of America, UN Doc. A/HRC/WG.6/9/USA/1 (2010), para. 20.

${ }^{72}$ UN HRC, Summary Prepared by the Office of the High Commissioner for Human Rights in accordance with para.5 of the annex to Human Rights Council Resolution 16/21: United Kingdom of Great Britain and Northern Ireland, UN Doc. A/HRC/ WG.6/1/GBR/3 (2008), para. 35.

${ }^{73}$ UN HRC, National Report in accordance with para.5 of the annex to Human Rights Council Resolution 16/21: Sweden, UN Doc. A/HRC/WG.6/21/SWE/1 (2014), para. 29; UN HRC, Summary Prepared by the Office of the United Nations High Commissioner for Human Rights in accordance with para.5 of the annex to Human Rights Council Resolution 16/21: Sweden, UN Doc. A/HRC/WG.6/21/SWE/3 (2014), para. 65.

${ }^{74}$ For wider discussion on retrogression see B. Warwick, 'Unwinding Retrogression: Examining the Practice of the Committee on Economic, Social and Cultural Rights', (2019) 19 Human Rights Law Review 467.
} 
reader to experience temporalities characterized by regressing movement. For instance, data can denote that protection of a right has worsened since the last review, ${ }^{75}$ or a new piece of legislation can demonstrate where previously held rights have been eroded. ${ }^{76}$ In these instances temporal rhythms are reversed by the network of author(s), compiler(s), readers, and objects: the time created is one of moving backwards instead of forwards or standing still. Nevertheless, on the whole, linear temporalities are a recurring theme in this stage of the review.

Besides advancing a linear connection between past and present, futures are also envisaged in a linear way. This is particularly common in national reports in light of OHCHR guidelines which indicate that 'key national priorities, initiatives and commitments that the State concerned ... intends to undertake' should be included in the submission. ${ }^{77}$ Action plans, draft bills and other planning documents frequently invite the reader to imagine a positive, premeditated future for human rights in the SuR which will follow from the present. Additionally, familiar from discussion of progress above, sometimes futurity is created via objects such as formatting devices and punctuation which are internal to the document. For example, a bullet point list or enumeration of issues to be addressed by the SuR might be included, ${ }^{78}$ or a dedicated section with a heading of 'National Priorities'. ${ }^{79}$ Through these formatting techniques, the report encourages the reader to encounter and buy into a future which is in the control of the SuR and is within linear comprehension. ${ }^{80}$ Equally, action plans, draft bills, etc. in UN and stakeholder reports can act in a differing way, indicating, for instance, that action plans have not been resourced effectively, or that draft legislation is not likely to be enacted. In these cases, a dispute arises as to the form the future following the present will take. This leads to a final temporality of note which is generated in this first stage of the review: discontinuity.

In the competing constructions of time discussed above - past, present, future, progress, lack of progress, retrogression - the reader is faced with differing, sometimes directly competing, accounts of the human rights situation in the SuR, activity against recommendations received, and plans for the future. Discontinuity is created as a result. Data, external documents, and other objects in the national report may paint a very different picture than the stakeholder and UN summaries. The human author of the report may be aware of this, seeking to engage and place these objects consciously to present a different temporal narrative than that of another advanced

\footnotetext{
${ }^{75}$ For example, data on homicides in UN HRC, Summary Prepared by the Office of the High Commissioner for Human Rights in accordance with para. 5 of the annex to Human Rights Council Resolution 16/21: Guatemala, UN Doc. A/HRC/ WG.6/2/GTM/3 (2008), para. 9; data on decreasing women's representation in Parliament UN HRC, Compilation Prepared by the Office of the High Commissioner for Human Rights in accordance with para.5 of the annex to Human Rights Council Resolution 16/21: Brazil, UN Doc. A/HRC/WG.6/13/BRA/2 (2012), para. 40; data on increase in sexual violence in UN HRC, Summary Prepared by the Office of the High Commissioner for Human Rights in accordance with para.5 of the annex to Human Rights Council Resolution 16/21: Sweden, UN Doc. A/HRC/WG.6/8/SWE/3 (2010), para. 19.

${ }^{76}$ For example, in China's second review the UN compilation report noted amendments to legislation which would legalize enforced disappearances: UN HRC, Compilation Prepared by the Office of the High Commissioner for Human Rights in accordance with para.5 of the annex to Human Rights Council Resolution 16/21: China, UN Doc. A/HRC/WG.6/17/ CHN/2 (2013), para. 4; in The Gambia's second review the stakeholder report noted legislation further restricting freedom of expression: UN HRC, Summary Prepared by the Office of the High Commissioner for Human Rights in accordance with para.5 of the annex to Human Rights Council Resolution 16/21: Gambia, UN Doc. A/HRC/WG.6/20/GMB/3 (2014), para. 10.

${ }^{77} \mathrm{UN}$ HRC, supra note 51, para. 2(F).

${ }^{78}$ For example, UN HRC, National Report in accordance with para.5 of the annex to Human Rights Council Resolution 16/21: Afghanistan, UN Doc. A/HRC/WG.6/5/AFG/1 (2009), para. 89; UN HRC, National Report in accordance with para.5 of the annex to Human Rights Council Resolution 16/21: Germany, UN Doc. A/HRC/WG.6/16/DEU/1 (2013), para. 76.

${ }^{79}$ For example, UN HRC, National Report in accordance with para. 5 of the annex to Human Rights Council Resolution 16/21: Israel, UN Doc. A/HRC/WG.6/3/ISR/1 (2008), at 20-1; UN HRC, National Report in accordance with paragraph 5 of the annex to Human Rights Council Resolution 16/21: South Africa, UN Doc. A/HRC/WG.6/13/ZAF/1 (2012), at 10-11; UN HRC, National Report in accordance with para.5 of the annex to Human Rights Council Resolution 16/21: Nigeria, UN Doc. A/HRC/WG.6/4/NGA/1 (2009), at 15.

${ }^{80}$ For broader discussion of linearity and futurity in international human rights law see K. McNeilly, 'Are Rights Out of Time? International Human Rights Law, Temporality, and Radical Social Change’, (2019) 28 Social and Legal Studies 817.
} 
in the process - for example, one of lack of progress or retrogression as opposed to a SuR's assertion of progress. This is not to say, however, that the human actant has full agency in this situation or is in a hierarchical position in the network. The object engaged may produce different effects from those intended, for example. The task of reviewing states is to navigate the discontinuity which emerges from the documents and the work of their various external and internal objects in collaboration with the author(s)/compiler(s), assess it, and generate resulting recommendations with a future-facing focus. The UPR's navigation of the discontinuous temporalities generated within it has been a theme discussed in scholarly literature to date. ${ }^{81}$

\subsection{Stage two: The UPR Working Group}

Following submission of documentation, the transmission of the final reports in electronic form, and their perusal by reviewing states, the UPR Working Group meets in the iconic Salles XX. This event represents the centrepiece of the UPR process: the occasion where the SuR faces peer review, discusses their human rights record, and receives recommendations for action. ${ }^{82}$ In this session, time is very much at the forefront. Each review lasts for three and a half hours. The SuR is allocated 70 minutes for its opening presentation, responses to questions, and final comments. The remaining 140 minutes are divided equally between states wishing to make statements. ${ }^{83}$ Depending on demand, speaking time for each state can be less than two minutes. ${ }^{84}$ These time constraints are frequently recalled as the President chairing the session reminds delegates of the speaking time, as large screens count down time in the room, and as speakers are cut off when their time has elapsed. However, time is more than just an external constraint acting on the interactive dialogue. This session in and of itself creates temporalities in important, and material, ways.

The first of these temporalities is stimulation of a collective present. The meeting brings together states to take part in an exchange designed to happen in real time - witnessed by observers in the public gallery and viewers watching the webcast - and to contain significance that will outlast its three-and-a-half-hour duration. To facilitate this, state delegates must physically travel to Geneva and are arranged in fixed seating in Salles XX. ${ }^{85}$ In generating this collective present, a range of objects are imperative. To attend the Working Group, delegates must use an official UN badge to access the premises. After showing this badge at the security checkpoint, following signposts to the correct building, traveling via stairs or lift and entering Salles XX, delegates take their seats. A laminated card on the desk in front of each delegation indicates the state they are representing. A designated desk at the front of the room seats the SuR delegation, the Human Rights Council President and Secretariat staff. Once these objects have facilitated physical access to the room and the appropriate seat within it, a range of other actants join in the creation of the collective present. Microphones are essential to project the voice of speakers, and headphones facilitate the transmission of simultaneous translation in the six official languages of the UN. Electricity is fundamental to power these objects and is available to charge the laptops, phones and other communication devices that delegates may be using. The session is structured via the speakers' list - displayed on a screen and circulated in electronic form via the extranet - guiding who will

\footnotetext{
${ }^{81}$ See the collection of scholarship supra note 16.

${ }^{82}$ See W. Kalin, 'Ritual and Ritualism at the UPR: A Preliminary Appraisal', in Charlesworth and Larking, supra note 5, at 29 .

${ }^{83}$ See Charlesworth and Larking, supra note 58 , at 5.

${ }^{84}$ See Higgins, supra note 17; K. Milewicz and R. E. Goodin, 'Deliberative Capacity Building through International Organizations: The Case of the Universal Periodic Review of Human Rights', (2018) 48 British Journal of Political Science 513 , at 517.

${ }^{85}$ The physical nature of the review has indeed been a subject of critique given the significant resources required for delegations to travel to Geneva, especially those representing low-income states. See R. K. M. Smith, 'Equality of "Nations Large and Small": Testing the Theory of the Universal Periodic Review in the Asia-Pacific', (2011) 12 Asia-Pacific Journal of Human Rights and the Law 36.
} 
speak and when, and the aforementioned screens visibly count down speaking time. When speaking, delegates read from prepared statements printed on paper or on a laptop or iPad screen which have been emailed to the UN Translation Service in advance. This diverse network facilitates and ensures smooth running of the collective present in the room. As noted above, however, wider audiences are also part of this present via live transmission of the session. Video cameras facilitate access for anyone in the world who can avail of a computer and internet connection. Alongside this, phones and laptops used within the room allow designated Secretariat and UPR Info staff to post live updates from the Working Group on social media.

In addition to creating a collective present which expands beyond the physical boundaries of Salles XX, human-nonhuman networks also generate temporalities pertaining to the past and future in the Working Group. Similar to stage one, a sense of the past in the present is created as the history of the SuR, its human rights challenges, and achievements are discussed. The prepared statements read out by delegates - from the SuR or reviewing states - may reference objects such as the UPR reports or other UN documents, international treaties or national legislation, dates of significance, etc. These objects assist in painting a picture of the past human rights record in the SuR and the linear progress, or lack of progress, which has been made in advancing human rights. The future is also constructed and takes an even stronger form than in stage one. This occurs, specifically, via the offering of recommendations by reviewing states. Fitting with the aim of the UPR to be 'action-orientated', 86 statements made throughout the interactive dialogue contain anywhere from one to six recommendations which the SuR is asked to address in improving its human rights record. In the session, these recommendations operate as objects generating a future-focus. Drafted in advance and read out from hard copy or electronic documents, their invocation creates a sense of a future which will follow progressively from the present and which can be foreseen or anticipated. This is a better future where the specific human rights concern at hand is addressed towards ever-increasing rights protection. As in stage one, recommendations promote an approach to the future as a temporal state that can be mapped out and managed, shaped by the will of the SuR, and reached via linear progress from the present moment. Recommendations are important in the Working Group not just because of their substantive content, but because they generate a forward-pushing impetus in the UPR as a whole, driving its work within an overarching narrative of linear time. They are, we might say, operators: ${ }^{87}$ objects so well placed they have power to direct the assemblage of the Working Group and the review overall. We will return to recommendations and the temporal ideas they help to create in discussion of stage three further below.

A further temporality generated in the Working Group is also familiar from stage one: predictability. This is evident in the structure of the session - comprised of an opening presentation from the SuR, the interactive dialogue, and final remarks from the SuR - as well as within each of these elements. Contingency is carefully managed and, as with the UPR documentation, the participant or observer of the session can predict much of what will occur within it in form, if not always in substance. Nonhuman actants are essential in this. For example, states are invited to submit written questions to the SuR in advance, which are placed in a Word document on the extranet and the OHCHR website. The questions contained in this document are usually addressed by the SuR in its opening presentation ${ }^{88}$ alongside the highlighting of pertinent information from the national report. In the next element of the session, the interactive dialogue, while its name suggests a contingent and fairly spontaneous exchange, in practice this is not the case. ${ }^{89}$ The reliance on scripted

\footnotetext{
${ }^{86}$ See UN Doc. A/HRC/RES/5/1 (2007), supra note 10, para. 3(d).

${ }^{87}$ Deleuze and Guattari, supra note 3, at 324-5.

${ }^{88}$ Although a state can strategically avoid addressing these questions: R. Chauville, 'The Universal Periodic Review's First Cycle: Successes and Failures', in Charlesworth and Larking, supra note 5, at 95.

${ }^{89}$ Jane K. Cowan describes the UPR's public moments, such as the interactive dialogue, as 'rigid' and 'highly ordered': Cowan, supra note 5 , at 51 .
} 
statements, in combination with the speakers' list set beforehand and the onscreen clock counting down individual speaking time, generates a predictable rhythm for the session. More generally, formalities and diplomatic etiquette, as well as the consistent positioning of states, chairs and desks in Salles XX also generate predictability, even repetition, across all reviews. The result of the work these various actants perform is that it is easy to tell what a Working Group meeting will look like and involve; predictability is its temporal driver. Indeed, stimulating predictability is important to achieve equality and universality in the process as well as maintaining the ritualistic nature of the review. ${ }^{90}$

Yet, this is not to say that unpredictability, contingency and disruption are never observable. On the contrary, these temporalities also emerge in various guises via the networks of the collective present. This occurs when, for example, objects fail and demonstrate a vibrancy that eludes their human users. ${ }^{91}$ A microphone can cut off or not work when intended to. Words on a prepared statement can escape the control of the speaker, tripping him or her up and disrupting the flow. The speakers' list may confound a state delegate who misses her cue. Unpredictability and contingency are also generated as the SuR receives questions and comments not anticipated or made available in advance. In these circumstances, notes are written between members of the delegation, information may be retrieved from a phone or laptop, and printed statements modified via pens. On rare occasions, a more profound sense of contingent disruption is created. One example of this occurred during Israel's second review. In May 2012, Israel suspended its membership of the Human Rights Council. ${ }^{92}$ This suspension, lifted just before the review in late 2013, led the national report to be submitted only the day before the Working Group met. In the interactive dialogue some discontent was evident as a result. ${ }^{93}$ However, significant disruption, was generated by states wishing to make points of order. These related to various issues, including procedural points. States interjecting, and retorts from the SuR, led to a stopping and starting and an interruption to order that caused the session to overrun the time allocated. The President sought to regain control as the session spiralled in an unpredictable direction. In generating this temporal disruption, objects such as prepared point of order statements, a flag used to raise the point, and relevant UN documents on procedure that were invoked, were all essential and worked alongside delegates. Thus, from minor incidents to this more substantial example, the actor-networks of the Working Group generate temporalities which not only sustain predictability but also break with it.

The final temporal flow created in this stage is affective in nature: a stretching of time which may lean towards boredom. ${ }^{94}$ Anyone who has observed a Working Group session, or watched its entirety on webcast, will perhaps have experienced this. In the three-and-a-half-hour-long session, one can often notice the yawns of delegates, their drooping posture, and their distracted use of phones or laptops as evidence of this temporal experience. The prepared statement documents physical objects held and read out by delegates - in particular contribute to the generation of time stretching in this way. This includes the opening statement from the SuR, which is usually the longest unbroken monologue and may sometimes simply repeat information in the national report or move from issue to issue with little in the way of dynamic delivery. The formulaic format of statements made by reviewing states and the repetitive rhythm of moving from one delegate to another in the frequently long speakers' list, which moves along on the screen at the front of the room, often has the same effect. The layout of desks, straight-back chairs, and the formal attire

\footnotetext{
${ }^{90}$ Charlesworth and Larking, supra note 5; Milewicz and Goodin, supra note 84, at 527.

${ }^{91}$ J. Bennett, Vibrant Matter: A Political Ecology of Things (2010), 5; B. Brown, 'Thing Theory', (2001) 28 Critical Inquiry 1 , at 4 .

${ }^{92}$ Discussed in R. Freedman, 'The United Nations Human Rights Council: More of the Same?', (2013) 31 Wisconsin International Law Journal 208.

${ }^{93}$ See comments from Nigeria and Iran: UN HRC, Report of the Working Group on the Universal Periodic Review: Israel, UN Doc. A/HRC/25/15 (2013), paras. 25, 99.

${ }^{94}$ Billaud too recalls this in her experience of the OHCHR report compilation process: See Billaud, supra note 5, at 68-9.
} 
worn by those present also contributes to this affective experience. ${ }^{95}$ Time stretching is thus a physical as much as a mental experience, and one that is co-created by objects in the room. ${ }^{96}$ In this observation of boredom as materially generated in the Working Group we see how objects in the UPR have an 'affective life', ${ }^{97}$ and one that is specifically temporal in nature.

Following the close of the review session, the Working Group will meet again within a few days to adopt the draft report. This shorter meeting - scheduled for 30 minutes - is again preoccupied with time as an external constraint. Yet, as with the previous meeting of the Working Group, time is not merely an external constraint acting on this session but is created within it. In particular, return is a defining temporality at this point of the process. The session allows for a return to the past - namely, the interactive dialogue - and an altering of it in offering opportunity to revise or amend the draft report. State delegates are informed of the date by which they must submit editorial changes to the summary section of the report via email - usually within two weeks - and advised that any changes to the recommendation section must be made in the present session itself. States may also contact the troika in the period between the review and adoption sessions to request changes. The revisions made are intended to correct an error or inaccuracy in the record. However, a practice has emerged whereby states may alter the nature, wording or substance of a recommendation following negotiation with the SuR. ${ }^{98}$ In the latter case, this usually serves to weaken the strength of the recommendation and thus effects a significant revision to the past of the interactive dialogue. The draft report document, written communications, email accounts, the delete button on a keyboard, the flag raised to draw the chair's attention in the session, the corridors, cafés and bars where negotiations take place between states, and other objects are central in achieving this revisionism and generating a temporal movement which eschews linearity. In this meeting of the Working Group time does not follow a linear progression between past, present and future, but the past can be returned to and revised, and is done so in a material way. A footnote placed after a recommendation in the report is a tangible indicator of this revisionism, detailing the changes made and doing the work of this non-linear return to amend the past. $^{99}$

\subsection{Stage three: Adoption of the Final Report at the Human Rights Council Plenary}

After the Working Group meets, a period of delay occurs. Several months elapse until the Plenary takes place, adopting the final version of the report under Agenda item 6. The report then becomes the official outcome document from the review. This delay is of temporal significance. It serves to generate a suspension of time in the review process, placing participants in limbo until the Plenary. In addition to being created by calendar dates and the schedule of the Human Rights Council, a suspension of time at this point in the review is also generated materially via the addendum document. The SuR may accept or note recommendations made to it at the same time as the Working Group or, more realistically given the increasing number of recommendations made as cycles have progressed, ${ }^{100}$ the SuR can elect to communicate its responses at a subsequent date. This must occur no later than the Plenary session. ${ }^{101}$ This is achieved via submission of

\footnotetext{
${ }^{95}$ See comments on the ritual of the UPR as an 'embodied performance': Charlesworth and Larking, supra note 58, at 9.

${ }^{96}$ For wider discussion on boredom and materiality see B. Anderson, 'Time-Stilled Space-Slowed: How Boredom Matters', (2004) 35 Geoforum 739.

${ }^{97}$ See Billaud, supra note 5 , at 64 .

${ }^{98}$ See Chauville, supra note 88 , at $99-100$.

${ }^{99}$ For final reports featuring significant footnote revisions see UN HRC, Report of the Working Group on the Universal Periodic Review: Peru, UN Doc. A/HRC/22/15 (2012); UN HRC, Report of the Working Group on the Universal Periodic Review: Sweden, UN Doc. A/HRC/15/11 (2010).

${ }^{100}$ In the first cycle 21,355 recommendations were made compared with 36,331 in the second and, as of July 2020, 22,374 in the third: www.upr-info.org/database/statistics/index.php (accessed 31 January 2021).

${ }^{101}$ See UN Doc. A/HRC/RES/5/1 (2007), supra note 10, paras. 28-32.
} 
an addendum outlining which recommendations have been accepted, which have been noted, and usually containing some explanatory commentary. If electing to communicate via an addendum, in the intervening period until the Plenary the SuR's responses are unknown. ${ }^{102}$ Sometimes this limbo extends further in cases where a SuR neglects to submit an addendum at all. ${ }^{103}$ On these occasions, the suspension of time continues until the next review, potentially creating difficulties when it comes to assessing the fulfilment of recommendations received in the next review cycle. ${ }^{104}$ Thus, in the period following the Working Group we see suspension being generated not only by human actors but by the Human Rights Council schedule, the addendum file, and the email and internet connection which facilitate submission of the latter to the Secretariat.

When the Plenary session does occur, it lasts for one hour. The session is broken down into three 20-minute periods. The first is allocated to the SuR to make comments responding to the review and its outcome; the second to other states who wish to make statements; and the third to NGO and NHRI stakeholders who are permitted to deliver statements. Here, again, a temporal focus on the past is brought into being. The preceding review and its outcome are recalled via the report document as well as prepared statements from the SuR and other participants. Ideas of the future are also stimulated as commentary often engages recommendations and any voluntary pledges or commitments made, the SuR either using these distinct bodies of text to convince that future improvement will occur, or other speakers urging the SuR to live up to the recommendations accepted and pledges or commitments made. As in previous stages, the future which is generated by speakers and their interactions with these objects - reports, recommendations, commitments or pledges, prepared statements - follows in a linear way from the present as well as appearing predictable and within the control of the SuR.

Perhaps the most interesting temporality generated in the Plenary session, however, is that of discontinuity. This emerges via the involvement of NGO and NHRI stakeholder actors. The rationale for their inclusion at this point is not to formally contribute to the review or make amendments to it, but to comment on its outcome. In addition to urging the SuR to action the recommendations accepted, these representatives can draw attention to issues which may have been omitted in the review, highlight recommendations that were not accepted and, on occasion, draw attention to any alleged bad faith engagement or other developments on the part of the SuR. Objects which facilitate this temporal creation include the badges which NGO, NHRI and stakeholder actors must apply for to enter the Palais des Nations, the written statements they may submit in advance, statements they read out via hard copy or screen, cards placed on the table indicating which organization they represent, microphones which project their voices, headphones which transmit the simultaneous translation, etc. Indeed, we could also consider the computers, forms, internet connections, passports, organizational logos and related objects which are essential to the accreditation process in the first place and facilitate their access to the Plenary session. NGO and NHRI actants are just one part of the network that creates this important temporality, objects are equally crucial in facilitating the delivery of stakeholder perspectives which may diverge from the narrative presented by the SuR or other states and would otherwise go unheard.

Following the final adoption of the report - often punctuated with a gavel wielded by the President ${ }^{105}$ - the outcome document is made available on the OHCHR website. This document emerges from relations between Secretariat staff, computers, software, recordings listened to via

\footnotetext{
${ }^{102}$ Often addenda are submitted just a few days before the Plenary, giving little time for reading of the state's response to recommendations: Chauville, supra note 88 , at 95-6.

${ }^{103}$ For example, South Africa first cycle; Albania first cycle; China first cycle; Democratic People's Republic of Korea first cycle; Democratic Republic of Congo first and second cycle.

${ }^{104}$ This was noted by Human Rights Watch regarding South Africa in UN HRC, Compilation Prepared by the Office of the High Commissioner for Human Rights: South Africa, UN Doc. A/HRC/WG.6/13/ZAF/2 (2012), para. 26.

${ }^{105}$ On the gavel as an object see J. Parker, 'The Gavel', in Hohmann and Joyce, supra note 2, at 214.
} 
headphones, ${ }^{106} \mathrm{UN}$ templates, section headings, paragraph numbers, and a UN document number. Working together, this human-nonhuman network captures the collective present of the interactive dialogue (plus any revisions) for the future in an enduring way via. Its upload to the OHCHR website renders this present accessible, alongside the webcast archive: it can be downloaded by anyone the world over who wishes to observe the particular present of the review session in question. The final report ends with the list of recommendations emerging from the review, serving to gesture towards the future which the review hopes to generate. In addition to creating futurity - as discussed above - the list of recommendations contained in the final outcome document also generates and sustains cyclicality. This list provides the basis for the next review and for activity in the intervening period. The cyclicality generated by recommendations in the final report is now reinforced by an infographic created by the Secretariat and placed on the UPR documentation webpage for each state. This infographic - featuring bar charts, pie charts, etc. - visually maps the volume of recommendations accepted and noted, as well as a breakdown of the thematic areas of the recommendations received. ${ }^{107}$ Readers are encouraged to use the infographic, alongside the list of recommendations, to think about a state's engagement with the UPR in a long-term cyclical way.

\subsection{Stage four: Follow-up to the Review}

It is important to stress that the UPR does not conclude with the Plenary session and begin again four to five years later when the next set of review documentation is submitted. Rather, in this intervening period the SuR is expected to undertake follow-up activity that serves to implement the recommendations it has accepted. ${ }^{108}$ In this fourth stage of the process time creation activities continue. In particular, following on from the above, a temporal rhythm of cyclicality is maintained. This is achieved via the work of civil servants, politicians and lawmakers within the state who must act on the outcome of the review, as well as wider civil society, NHRI and NGO stakeholders who hold the Government to account in this activity. A range of objects are important in maintaining a cyclical momentum in the follow-up, beyond the list of recommendations noted above. One of the most important objects is the mid-term report which states are encouraged to submit at the half-way point between reviews. Submission of this report is voluntary. As of February 2021, 121 mid-term reports have been submitted across the three cycles of the review. ${ }^{109}$ Where states do produce a mid-term report, their representatives email the file to Secretariat staff for upload to the OHCHR website. These actants, and the relationality between them, works to solidify the cyclical operation of the UPR, strengthening the periodicity of the system and its calendar in a public way.

In addition to the voluntary mid-term report document, however, other objects at the national level stimulate cyclicality. These include action plans based on the UPR outcome that may be developed by the state, ${ }^{110}$ new policies and legislation created in response, UPR websites updated with follow-up action, ${ }^{111}$ and tables detailing actions and progress made are often created in this

\footnotetext{
${ }^{106}$ See Billaud, supra note 5, at 69.

${ }^{107}$ See information on individual states at www.ohchr.org/EN/HRBodies/UPR/Pages/Documentation.aspx (accessed 31 January 2021).

${ }^{108}$ See UN Doc. A/HRC/RES/5/1 (2007), supra note 10, paras. 33-8.

${ }^{109}$ Mid-term report information is listed at www.ohchr.org/EN/HRBodies/UPR/Pages/UPRImplementation.aspx (accessed 28 February 2021).

${ }^{110}$ See B. Schokman and P. Lynch, 'Effective NGO Engagement with the Universal Periodic Review', in Charlesworth and Larking, supra note 5 , at 140 .

${ }^{111}$ For example, New Zealand's UPR webpage, available at www.mfat.govt.nz/en/peace-rights-and-security/human-rights/ universal-periodic-review-2019/ (accessed 31 January 2021).
} 
follow-up period, to be referenced in the subsequent review cycle. ${ }^{112}$ At the international level, Geneva-based NGO UPR Info also contributes to maintenance of cyclicality in the follow-up period. Established in 2008, the organization has created databases, training resources, newsletters, quantitative analyses, and other publications which seek to stimulate engagement with the UPR throughout the whole of its cycle by states, but especially by national and international NGOs. The network of UPR Info staff and interns, the organization's website and social media accounts, its training materials and documentation available online also assist in the creation of a cyclicality in intervening years, again contributing to the wider bolstering of the UPR calendar overall.

As in other stages of the review, however, cyclicality is not the only temporality created. In follow up rhythms of discontinuity are also frequently constructed. In this stage such occurs when states do not follow up or action recommendations that have been accepted. Here the final working group report, recommendations within it, and human actors within government and state administration coincide in networks to create a discontinuity which may frustrate smooth and continuous cyclical flows.

\section{Why should time mattering in the Universal Periodic Review matter?}

Following this exploration of the micro and everyday ways in which diverse, overlapping and competing ideas of time are created materially in the UPR, what overarching insights might be drawn? Or, more pointedly, why should international human rights scholars and practitioners interested in the UPR pay attention to these methods of time creation? A number of points can be made in response that unpack the significance of the preceding analysis. First, the exploration above provides a lens through which scholars and practitioners can understand the UPR anew, as if for the first time. As noted at the outset, the temporalities created throughout this mechanism, and the assemblages that facilitate them, are highly naturalized and taken for granted. Computers, files, microphones, and email accounts, for example, often blend into the background of the process rather than being apprehended as actants performing work which drives the review and its temporal nature. It is their mundanity which allows these networks and their importance to be overlooked. Addressing this to take a closer look at human-nonhuman networks and the temporal effects they generate, allows scholars and practitioners to see the UPR as relational and, through this, productive in ways previously not understood.

As Emilie Cloatre reminds us, ${ }^{113}$ ANT serves at its heart to foreground relationality, and when engaged in legal domains facilitates a rethinking of these domains as themselves highly relational. This relationality extends beyond humans working in co-operation to encompass objects as coactants in legal processes and events. From this relationality an ANT-inflective perspective suggests that productive results flow; it is the social itself that law's relational processes produce. ${ }^{114}$ The investigation of the four formal stages of the UPR above and time creation within them brings the relationships at the heart of this mechanism into view in fresh ways and assists us to begin to understand the review's capacity to produce the social world through these relations. Rather than regarding the UPR as a formalistic and bureaucratic process, it is possible to see how it contains wider, world-making power in its everyday activity. Specifically, I advance that the productive work of relations between actants in the UPR produces social ideas of time more widely. For instance, we can see that the UPR operates to foreground modern, linear approaches to time, ${ }^{115}$

\footnotetext{
${ }^{112}$ For example, Kenya's implementation matrix, available at www.upr-info.org/sites/default/files/general-document/pdf/ kenya_2nd_cycle_final_matrix_2016.pdf (accessed 31 January 2021).

${ }^{113}$ E. Cloatre, 'Law and ANT (and its Kin): Possibilities, Challenges, and Ways Forward', (2018) 45 Journal of Law and Society 646.

${ }^{114}$ See Latour, supra note 4 , at 8.

${ }^{115}$ R. Koselleck, Futures Past: On the Semantics of Historical Time (translated by K. Tribe) (2004); R. Friedland and D. Boden (eds.), NowHere: Space, Time and Modernity (1994).
} 
but that it also contains and advances other approaches where discontinuity, return or cyclicality are central. The relational work of the UPR shapes the place of these temporalities within the socio-legal practice of international human rights, and our understanding of human rights through these lenses of time, but also - arguably - contributes to their discursive place in social life more generally. The UPR does not take place isolated from social understandings of time, ${ }^{116}$ but is caught up with, indeed operates to create or further reinforce, such understandings as an actor-network. Thus, when we grasp the UPR as a collection of relational temporal assemblages, its operation becomes defamiliarized and capable of being examined from fresh angles, including in terms of the social realities it helps to produce or reiterate.

Second, once participants better understand the UPR as made up of relational networks and apprehend the work these networks perform, they can begin to consider new or amended ways to approach the process. As part of this, state delegates, civil society stakeholders, and Secretariat staff may more thoughtfully engage with objects across the review's stages. Human participants must move beyond apprehension of objects as resources or passive things to be used, and instead reapproach them as co-actants with a dynamic role in the UPR and its (temporal) outcomes. Alongside data, action plans, computers, microphones, bullet points and lists, a particularly important set of actants which might be engaged more consciously in the process are recommendations. Rather than just words and sentences constructed and read out by state delegates, recommendations can be apprehended as objects with agentic power to generate ideas of progress/ lack of it, to give the review a future-facing temporality, to maintain the cyclicality of the review, or to explore the past and state adherence to human rights obligations within it. One observation that has been made as the UPR has matured, pertains to the relatively limited focus on previous recommendations in subsequent interactive dialogues. ${ }^{117}$ While some reviewing states do refer back to recommendations made in the previous cycle, the focus is usually on the generation of new, additional recommendations to be taken forward. The future-focused drive recommendations contain has therefore been engaged to a greater extent than their generation of cyclical continuity or scrutiny of the past. It is important to consider the role these actants are playing in the temporal patterns becoming established in the review. Human participants may reflect on their own relationship with recommendations and how this might, in various locations and contexts, be experimented with to aim to stimulate temporalities of the past and cyclical continuity, in addition to futurity in holding states to account.

As part of this approaching of the UPR differently, it is also possible for participants to begin to consider any limitations of current temporalities created by actor-networks and seek to address these limitations. For example, flowing from the UPR's production of modern approaches to time, the futurity which has emerged from the work of these networks has been, as discussed, one that is linear in nature, can be mapped out in advance, and can be directed by the SuR. This forecloses that the future may not follow in such a linear and progressive way from the past and present, and how this may lead to the need for a more fluid and open understanding of the future to be integrated into the UPR process. ${ }^{118}$ At present objects are not working in relation with humans to bring this kind of approach to the future into view, but perhaps alternative visions of the future as a temporal domain need to be discussed to better grasp the reality of human rights practice and how it may often generate futures which are non-linear and not under human control. It is not possible to assert that humans can, or should, seek to straightforwardly employ, use or direct objects to generate such an alternative conception of the future. Such behaviour departs too starkly from the ontological symmetry ANT advances. It is possible, however, to start new conversations on the dominant temporal logics produced in the process from observation of their creation. Beginning these conversations is a starting point in creating space to encounter and understand

\footnotetext{
${ }^{116}$ See also Greenhouse, supra note 45 in the context of national law.

${ }^{117}$ See Bertotti, supra note 11 , at 1152 .

${ }^{118}$ See McNeilly, supra note 80 for discussion of such a future in international human rights law.
} 
messier, unknowable, non-linear future trajectories for human rights which better reflect the reality of the temporal flows of our everyday lives. ${ }^{119}$

Third, and finally, focusing on the UPR as one site of networked time generation can offer a starting point for analysis of the production of time in international human rights law more broadly. In ANT's opening of the various black boxes of science, technology and wider phenomena, attention is often drawn to 'punctualization'. This refers to how actor-networks in one black box become linked together with others to create larger networks. As Callon comments, 'the process of punctualization thus converts an entire network into a single point or node in another network'. ${ }^{120}$ In this process actor-networks themselves become actors in other networks which are bigger in scale. Engaging this in the present context, we might understand the complex temporal life of the UPR, the sets of fluid actor-networks which make it, as just one node within a wider actor-network of time creation in international human rights law more generally. As a time creating phenomenon, this legal system is made up of many human-nonhuman networks containing various places where one discrete black box system is punctualized into the wider network of time creation which characterizes this system as a whole. The next step is to begin to think through this bigger network, and other nodes within it, in ongoing work to gain a deeper and richer grasp of the temporal nature of international human rights law. Writing on law and time at the national legal level offers a way into this activity, but the uncovering of the specific manner time is generated at the international legal level must be a unique endeavour. This begins with understanding individual temporal phenomena such as the UPR before mapping it out further towards an understanding of the bigger time creating actor-networks which these individual phenomena link into. While of course beyond the scope of this article, this possibility offers future avenues for scholarly consideration and the undertaking of work to gain a fuller grasp of the temporal character of international human rights law.

\section{Conclusion}

Patek Philippe is one of Geneva's most renowned clock and watch manufacturers. Since its establishment in 1839, the company has become one of the most distinguished in the world for its skill, innovation and creation of luxury timepieces. The company's notable achievements include development in 1845 of a pioneering keyless winding system; patenting in 1889 a new perpetual calendar for pocket watches; creating in 1956 the first ever all-electronic clock; and producing in 1989 the most complicated mechanical watch ever made. ${ }^{121}$ From this short list of accolades it is clear that Patek Philippe has been at the forefront of extending the role of clocks and watches as actants, pushing the boundaries of the work they can do alongside their human users in sustaining, and creating, ideas of time. In Geneva today Patek Philippe is widely and visibly celebrated in the city as another reminder of the close connection the region, and country more generally, has with time. When the visitor enters the Palais des Nations and adjoining UN buildings in Geneva - including Salles XX where the UPR Working Group sessions take place - the city's celebration of Patek Philippe does not end. All clocks in the UN premises - from the security queue to the hallways, from the library to the meeting rooms - are produced by Patek Philippe. In this respect, Geneva's history and reputation in developing the mechanical devices that have for centuries assisted in the construction of societal time is a physical presence in all activity which occurs in the UN's European headquarters. As the participant in, or the observer of, activity within these buildings checks the time, they can be reminded of their part in the complex assemblage of clocks, watches,

\footnotetext{
${ }^{119}$ On this point see E. Grosz (ed.), Becomings: Explorations in Time, Memory, and Futures (1999).

${ }^{120}$ M. Callon, 'Techno-Economic Networks and Irreversibility', in J. Law (ed.), A Sociology of Monsters: Essays in Power, Technology and Domination (1991), 132, at 153.

${ }^{121}$ N. Foulkes, Patek Philippe: The Authorized Biography (2017).
} 
mechanisms, electric charge, and humans across the world producing time as we know it in its standardized form.

However, following discussion in the preceding pages, I would encourage our participant or observer to go further than this to consider how wider objects in the rooms of the UN headquarters also have a role in the networked creation of temporal ideas, rhythms, and flows. The work of these objects in relation with humans is diverse, mundane, and often invisible. The UPR is one ideal case study of this material nature of time creation in international human rights law work. Looking closer at the UPR's public activity, we can see how computers, screens, seats, documents, email accounts, data, microphones, electricity, and a wider variety of objects operate in relational temporal assemblages or networks. The Patek Philippe clock is thus only one - and perhaps not even the most interesting - actant with time generating capacity present in the review process. Whether looking in on the UPR as a scholar observer, or participating in it as a human rights lawyer, diplomat or civil society representative, grasping the process as one defined by complex temporal rhythms created in various networks of actants is a powerful new key. It can unlock fresh ways of understanding the process and its operation, but also of approaching this monitoring practice and apprehending its temporal possibilities and potential limitations in the reviewing of states' human rights records. Rather than a backdrop against which the UPR takes place, the review process and the actants within it stimulate various temporalities from progress to retrogression, predictability to suspension of time, and in doing so contribute to international human rights law's wider operation as a site of temporal generation. In apprehending this relational generation of time, we must understand it as caught up with productive world-making, having social effects that may not be immediately obvious. Our work beginning to grapple with time in international human rights law begins, however, with apprehension of everyday time creation, with looking to objects beyond the Patek Philippe clock and simply following their activity anew.

Cite this article: McNeilly K (2021). How time matters in the UN Human Rights Council's Universal Periodic Review: Humans, objects, and time creation. Leiden Journal of International Law. https://doi.org/10.1017/S0922156521000169 